\title{
Vision of Death in Emily Dickinson's Selected Poems
}

\author{
Marwan Alqaryouti ${ }^{1}$ \& Ala Eddin Sadeq ${ }^{1}$ \\ ${ }^{1}$ Department of English Language, Literature and Translation, Zarqa University, Zarqa, Jordan \\ Correspondence: Marwan Alqaryouti \& Ala Eddin Sadeq, Department of English Language, Literature and \\ Translation, Zarqa University, Zarqa, Jordan. E-mail: mqaryouti@zu.edu.jo; alaeddin_english@zu.edu.jo; \\ Alaeddin71@yahoo.com
}

$\begin{aligned} & \text { Received: November 27, } 2016 \quad \text { Accepted: December 12, } 2016 \quad \text { Online Published: April 19, } 2017 \\ & \text { doi:10.5539/ass.v13n5p16 }\end{aligned}$ URL: https://doi.org/10.5539/ass.v13n5p16

This research is funded by the Deanship of Scientific Research at Zarqa University-Jordan.

\begin{abstract}
Poetry is greatly influenced by the cultural background and personal experiences of the poets. Emily Dickson's poems exemplify this because she draws a lot of her motivation from her heritage of New England and her life experience which had harsh incidents such as loss of friends and relatives. She lives a life of seclusion, where she rarely has face-to-face encounter with her friends as she prefers communicating through letters. Her limited interaction with the society gives her adequate space to reflect and write about different aspects of life. Emily's poetry is also influenced by the doubts she holds about Christianity, especially in relation with survival of the soul after death. "Because I Could Not Stop for Death" and "I Heard a Fly Buzz- when I Died" are among her popular poems that indicate her religious doubt. She agrees with some of the Calvinist religious beliefs, but still has some doubts about the innate depravity of mankind and the concept of the afterlife.

Dickinson's spiritual background is indicated by her religious beliefs, which form the basis of her preoccupation with death. Although Dickinson is a religious person who believes in the inevitability of death and afterlife, she is a non-conformist as she is skeptical and curious about the nature of death. Transcendentalism is the other factor that contributes to Dickinson's preoccupation with death as indicated in her poems. Dickinson's preoccupation with death also results from her obsession, which is greatly contributed by the life experiences she has with death including loss of her family, mentors and close friends.
\end{abstract}

Keywords: Life, Seclusion, Calvinism, Christianity, Afterlife, Death, Emily Dickenson, Transcendentalism

\section{Introduction}

The theme of death has been explored in literature frequently. Each writer, however, views death from a different perspective based on his/her experience. Emily Dickinson (1830-1886) is one of the writers who highlight the theme of death due to her unique experience and lifestyle. She, for instance, prefers seclusion to communicating with people; therefore, her poetry is a result of a deep mediation of the concepts of life, death and the afterlife.

This study aims at analyzing Dickinson's poems "Because I Could Not Stop for Death" and "I Heard a Fly Buzzwhen I Died" in the light of her perspective of death.

\section{Discussion}

\subsection{Emily Dickinson's Vision of Death}

One of the most captivating aspects about the literature of Emily Dickinson is her ability to present death in varying forms. She describes the different emotional responses that death has on human soul and mind and enables the readers to view death from a different perspective. The ambiguous meaning of death that Dickinson uses gives the audience a choice to have their own interpretations about death. Through the varying descriptions of death, the author explains the many types of death that individuals experience.

\subsection{Life after Death}

Death is presented as the beginning of eternal life in "I Heard a Fly Buzz when I Died" as the speaker explains the events that take place after her death. Her vision of death indicates the process of putrefaction that occurs when one dies (Yan, 2010). She explains that the room gets still when one dies, indicating that she is still 
conscious about her surroundings. In the poem, the speaker communicates beyond the grave, indicating that there is life after death. In the first stanza, the speaker explains that she hears the buzz after she dies but is able to provide an account of the events that take place after that.

Dickinson's vision about death in the poem, "Because I Could Not Stop for Death," also views death as the end of the worldly life and the beginning of eternity (Faur, 2012). The poem describes death in a romanticized way, where its civility allows it to wait for the poet to finish her activities. Dickinson describes death in a personified way, and indicates how it is patient and respectful. The concept of afterlife is indicated by the description that the poet gives about how death watches her finish her activities. Her vision about death is that it waits for one to accomplish their purpose in life, when it takes them to afterlife. In the first stanza, death is said to appear accompanied by immortality, an indication of life after death. In the third stanza, the author describes the various stages that she goes through in life before the physical death. The speaker describes how they pass through the world of the living beings to eternity. The passing of the school where children strove is a description of the world of the living to a life that was timeless (Dickinson, 1933). The timelessness of eternal life is indicated by the fact that the speaker passes the setting sun instead of the setting sun passing by.

\subsection{Separation of Body and Soul}

Dickinson's view about death is also characterized by the perception that the body and soul exist differently. She introduces the idea of separation of body and soul in the poem, "I Heard a Fly Buzz- when I Died," by describing her ability to understand the events that take place after her body dies. In the first stanza, it is clear that the poet is dead as indicated by the phrase - when I died-, but she still manages to explain the events that take place after her death. She describes the events in her new form, where she sees even the relatives who passed ion before her, citing that their eyes look tearless probably due to the peace of mind they experience in death. Even if the poet is dead, she can feel breaths gathering as she awaits to have the last breath. She cites that;

For that last Onset- when the King

Be Witnessed-in the Room- (Dickinson, 1933)

The words above indicate that there is a part of her that is still not dead, the soul and it awaits the inevitable death. The word King used by the poet may be interpreted as God by the religious people, but Dickinson's work is not strongly influenced by religion. This implies that the word King refers to death, indicating that she is yet to die completely. However, based on Christianity religion, one may conclude that Jesus is the King. It is believed that when one dies, their souls separate from the body and they live in afterlife in a spiritual form. The actual death of the body and the soul occurs at the end of the story, where the poet describes her inability to see anything, implying the death of the soul.

\subsection{Emily Dickinson's Obsession with Death}

Dickinson's obsession with death is indicated by the way the theme of death preoccupies her poetry. She does not only discuss about death of other people, but also her own demise and afterlife experience.

\subsection{Social Isolation}

One of the factors that contributed to Dickinson's obsession with death was her isolation from the society. In a normal social setting, individuals interact with their friends but this was not the case with Dickinson as she lived alone most of her life. Among the factors that are attributed to her choice of being alone was depression, which was mainly brought about by the experienced she had in life. Since the mid -1860 s, Dickinson preferred spending most of her time in the house and she would avoid communicating with people. She changed her method of communication from face-to-face method to writing letters, which again were sent to selected people. During the time that she was isolated from the other people, she developed a great interest in reading and writing. The other reason that could have influenced Dickinson's isolation from the community is her mother's failing health that forced her to spend most of her time at home. The quiet room that was next to her ailing mother's created a friendly environment for her to write. Additionally, she did not see the need to get out of the homestead as it offered her all the beauty she could get outside.

Her seclusion made her obsessed with death, which was considered as a mysterious aspect of life that nobody understood. Instead of fearing death like most of the members of the society, Dickinson chose to look at the positive side of it. Her obsession is indicated by the way that she personified death in her writings where she accords it human attributes such as patience and civility. In the poem "Because I Could Not Stop for Death," Dickinson cites that; 


\section{May labor and my leisure too, \\ For his civility- (Dickinson, 1933)}

She characterizes death as patient, and a being that follows her through all the stages in her life. Her obsession with death is indicated by the fact that she thinks of death as companion. She no longer thinks of death as frightening rather she considers it a familiar life companion. In her opinion, dying is a normal process that occurs in one's life. In the poem "I Heard a Fly Buzz- when I Died" death is likened to a fly that take away one's life. Dickinson's ability to view death in other imaginary forms is enhanced by her obsession.

\subsection{Dickinson's Loss of Close Friends and Relatives}

The obsession of the poet with death may also have been contributed by the death of her parents and close friends. Although she lived a life of seclusion, Dickinson maintained contact with close friends through letters hence implying that she had a social life. She was also very close to her immediate family as illustrated by her decision to stay at home and look after her mother. Sadly, she watched her close friends and relatives die of varying causes such as illnesses. Her obsession with death may have resulted from the need to know why people die and whether they exist anymore after death. She may have wondered whether it was possible to reunite with the dead in afterlife when one died. Her social seclusion may have made her long for the friends and wonder if their friendship would continue after death.

Dickinson lost mentors such as Edward Hitchcock, who she described as a persevering and hard working person. Evidently, she looked up to him, but his death rendered life meaningless. She also lost another mentor, Susan Huntington, who she described as the most knowledgeable person she knew. The loss of her father was another blow that made her interest in death more intense. She described her father as a man who had pure and terrible heart. She was certain that there would never be any other man like her father. She had learned to accommodate his autocratic ways and the two had a good relationship until he died. Dickinson could not understand the cause of her father's death as he is said to have collapsed while delivering a speech. The curiosity about death was further increased as she aimed at establishing the causes of death. Her mother's paralysis and demise further increased her obsession with death. Her brother Austin also died and this affected Dickinson's life greatly as she did not only lose a brother but a friend as well. The poet grew up with her sister Lavinia, but she watched her die as well. The death of her young nephew revealed that anyone could die, whether young or old. It may be the motivation behind the poem "Because I Could Not Stop for Death," where death is viewed as a lifetime companion (Faur, 2012). The obsession that Dickinson had about death was motivated by the need to understand its nature.

\subsection{Religious Influence}

Emily's obsession with death was partly influenced by the Christian teachings on life and death. Growing up in an era when religion was not very popular, Dickinson struggled between faith and doubt. Some of the religious concepts were inconsistent with the scientific ides developed. An example is the concept of human creation, where religion held that human beings were created by God, while the Darwinism theory explained that human beings existed through evolution, where the strong people outlived the weak ones. Although Dickinson was not a religious person, she was aware of the biblical teachings of life, death and eternity. In her young age, she attended religious services accompanied with her family where she was taught about the biblical teachings. Her obsession with death was brought about by the curiosity to determine whether the biblical perspective about life and death were true. In the poem "I Heard a Fly Buzz when I died." Dickinson indicates that;

\section{And Breaths were gathering firm- \\ For that last onset-When King - \\ Be Witnessed in the Room (Dickinson, 1933)}

Based on her Christianity religious background, one may conclude that the King referred to in the poem was Jesus Christ. The bible indicates that human beings exist in eternal life as souls where Jesus takes the righteous souls to heaven.

\subsection{Emily Dickinson's Attitude towards Death}

The poet's preoccupation with death influences her perceptions towards life, death and afterlife. One of the attitudes that she holds about death is that it is not the end of life. Instead, she holds the belief that death is the beginning of new life in eternity. In the poem "I Heard a Fly Buzz when I Died," Dickinson describes a state of existence after her physical death. In the state, she can feel breath gathering firm for the last onset, implying that she is still conscious although in the spiritual form (Dickinson, 1933). Onset refers to the beginning of something, and in the current case it refers to the beginning of eternal life. According to the Christian teachings, death brings 
about revelation and one continues to exist in a new form in heaven. In the poem "Because I Could not Stop for Death," the poet indicates that one exists even after death. In the second last stanza describes the grave as a swelling of the ground, indicating the death of the poet, but life continues even after the grave. Years or centuries after her burial, the poet still exists hence indicating that death is not the end of life. Dickinson's view about eternity may be motivated by religious teachings about life after death.

The other attitude that the Dickinson holds about death is that it is inevitable as one cannot escape it. In the poem "Because I Could Not Stop for Death," the speaker describes death as a life companion, who is with her throughout her life. She is overpowered by death as she indicates that they passed the setting sun instead of the sun passing them by. The speaker also indicates that death is inevitable by stating that it was patient enough to wait for her, even if she was busy carrying on with her daily routine. Death is described as a life companion that accompanies on everywhere they go, indicating that it is inevitable.

In the poem "I Heard a Fly Buzz when I Died" the speaker describes her inability to overcome death in her death bed. She explains her helplessness in the face of death where she indicates that the Fly interposed between her and the light, in this case life. The interposition of the Fly occurs at a time when she is giving her possessions away and she cannot stop it. In the second stanza, the speaker indicates her knowledge that she awaits death but she still waits for it. She expresses that the King would soon be experienced in the room, referring to death.

The other attitude that the speaker has about death is that it is cruel or cold. The loss of close friends and relatives is among the factors that influence Dickinson's perception of death as cruel. The loneliness and suffering she experiences because of their death greatly contribute to her judgment about death. The cruelty of death is expressed in the poem "Because I Could Not Stop for Death," the first line of the first stanza, which indicates that death takes away the speaker's life, even though she is still busy with her daily activities. It is clear that the speaker does not want to die but death waits for her and takes her life anyway. The speaker ironically describes death as kind, and applauds it for giving her enough time to complete her activities. In reality, the speaker finds death so cruel that it denies her the chance to live a full life and accomplish her goals. She describes how death drives her slowly to eternity, as it is accompanied by immortality -The carriage held but just Ourselves, and immortality- (Dickinson, 1933). The description of death as civil in the second stanza is also ironic and the speaker does not opt for it willingly. The speaker states that she puts away her labor and leisure in exchange for the civility of death. She does not literally mean that death is civil, but it is the only option left after she is unable to work or rest peacefully. In her opinion, death takes away one's peace of mind and they became restless.

The cruel nature of death is also indicated by the fact that they pass past the setting sun or the sun passes them. In a literal sense the passing of the sun may be the normal way it passes through the horizon, but the speaker uses the description to indicate the cruelty of death. The speaker shifts from the sunny days and enters a cold world, where she is uncomfortable. She indicates that

\section{The Dews drew quivering and Chill - \\ For only Gossamer, my Gown- My Tippet - only Tulle - (Dickinson, 1933)}

In the above lines, the speaker begins to realize the cruelty of death as it makes her feel uncomfortable. She experiences a cold feeling due to the thin material used to make the dress or the gown she wears. In the literal sense, one may assume that the cold experienced by the speaker is due to the Gossamer and Tippet that she wears, but it describes the cruelty of death. In literature, natural aspects such as cold, sunshine, sunset and seasons are used to describe different feelings by the author. In particular, cold represents sadness, loneliness and disillusionment. In the poem, the speaker uses physical cold to express the emotional or psychological pain that she experiences.

The cruelty of death is also evident in the poem "I Heard a Fly Buzz when I Died." The speaker uses a Fly symbolically to indicate the process of decay that the body undergoes when one dies. In the first stanza, the speaker indicates that she heard a fly even in her death, and goes on to explain the stillness in the room where she dies. In the third stanza, the speaker describes how death interposes between her and the life, preventing her from carrying on with the ritual of assigning her possessions. Death makes the speaker confused and she cannot comprehend anything $-I$ could not see to see. Although the speaker does not cite any painful experience of the dying process, she describes death as horrible and gruesome. It is clear that the cruelty of death does not only affect the deceased, but also their friends and relatives. In the poem, the speaker indicates that the people watching her die have no more tears as they have cried enough. She states -The eyes around-had wrung them dry -, indicating that they cannot cry anymore (Dickinson, 1933). The phrase wrung them dry is indicates the pain 
and suffering experienced by the bereaved.

\subsection{Emily Dickinson's Preoccupation with Death}

There is a great distinction between Dickinson's obsession and her preoccupation with death, as indicated in her poetry. Her obsession with death is irrational and cannot be explained, but her preoccupation describes her concern. Preoccupations are ideas that one cannot ignore, as in the case of Dickinson. As much as she may have wanted to stop thinking about death, she could not just wish the idea away. One may argue that Dickinson's obsession with death led to the preoccupation, where her primary focus entailed understanding death. The following are some of the factors that may have contributed to Dickinson's preoccupation with death;

\subsubsection{Transcendentalism}

This refers to the ability to think or conceptualize simple ideas beyond the reality, using intuition rather than senses. Individuals who embrace transcendentalism have high confidence in their beliefs, especially about what is right. Such individuals are not sensitive to the criticisms that people have about their lives as they mainly focus on what they believe to be right. Transcendentalism is one of the influences that had a significant impact on Dickinson's poetry, based on the fact that she was firm in her social and religious beliefs (Hughes, 2014). She expressed her beliefs in her poetry, without considering the opinions of her critics. In all her literature, it is clear that she was greatly interested in varying topics about life including immortality, death and faith. Her transcendentalism does not take the form of prophesy, but a search for the truth about life and death. Dickinson uses self-critique and self-analysis techniques to achieve her objectives (Doost \& Jamili, 2014). The preoccupation that the Dickinson has about death and life in general leads to her conclusion that death is inevitable and thus should not be feared.

In the poem, "Because I could not stop for death", the speaker indicates that death is inevitable as it takes her life when she is not prepared. In the first stanza, death is presented as a suitor who appears in her life and, although she is busy with other activities, death still takes her life away. She is too busy for death but this does not stop death from occurring. The speaker's busy schedule indicates that she is not ready to die, which is the case with everyone in the society. Everyone wants to live a good life and never die, but this is an unrealistic expectation according to Dickinson. In the poem, she indicates that human beings have no control over death.

\subsubsection{Spirituality}

Dickinson's spirituality is also an important aspect that influences her preoccupation with death. Spirituality refers to the connection or the link that one develops with the power $\mathrm{s}$ beyond their comprehension. In Dickinson's life, her spirituality is presented by religious beliefs that she holds (Ambarwati, 2006). Having been brought up in a Christian family, she understands the process of dying, as well as the concept of life after death. The basis of her religious beliefs is Calvinism, a type of Christianity that believes that salvation of the soul is a given to the selected individuals in the society.

Dickinson's preoccupation with death was mainly influenced by her curiosity about survival of the soul after death. Based on the Calvinism philosophy, Dickinson learnt about the survival of the soul after death and she was curious to know how this was possible. Although she agreed with most of teachings by the Calvinism philosophy, she was opposed to the belief that human beings have innate depravity. Instead she supported Puritanism, which stated that the soul was immortal. Her poetry was characterized by faith in life after death but also doubt about the same. In the poem "I heard a Fly Buzz-when I died," the speaker shows her doubt on whether there is life after death (Ambarwati, 2006). In the first stanza, the speaker indicates that she hears a Fly buzz but she is already dead. She goes ahead to describe the activities that take place at her deathbed including the presence of mourners, who seem ready for her death. She indicates that The Eyes around-had wrung them $d r y$-, indicating that the mourners already accept that she is dead (Morgan, 2010). It is clear that the speaker talks beyond her grave, indicating Dickinson's faith in life after death. However, her doubt about eternity is indicated in the third stanza where she states the reappearance of the Fly. Based on the nature of the insect, it is clear that the Fly symbolizes decomposition of the body. The speaker states that the Fly interposes between her and the light, when she was offering her possessions to the mourners. The Fly indicates that the speaker doubts eternity, as she believes that her body decomposes.

The influence of spirituality in Dickinson's preoccupation with death is also evident in the poem "Because I Could Not Stop for Death." To begin with, the speaker is in the form of a ghost as indicated by the fact that she is dead. In the first stanza, the speaker is alive but she later dies and leaves behind the living (Gallagher, 2007). Death carries her to the grave and she exists in the new form in eternity, indicating that Dickinson believes in life after death (Leiter, 2007). In Christian religious teachings, Jesus is regarded as the bridegroom who will only 
marry the brides who will be pure, indicating the importance of leading a righteous life. In the poem, the speaker's description of her dress resembles the bride's indicating her spirituality (Ickstadt, 2001). Additionally, death is described as a suitor whose intention is to woo the bride. However, Dickinson's doubt about the survival of the soul is shown by the fact that she does not hold any conversation with her suitor, death. Further, the speaker complains about the cold she feels due to her light material clothing. This indicates that the concept of life after death may not be as described by the religious teachings.

\subsection{The Experience of Dying in the Poem "I Heard a Fly Buzz when I Died"}

Dickinson describes the experience of dying as a painless but a horrifying one. The clarity of the dying experience explained by the speaker is enhanced by the fact that she speaks from beyond the grave. The speaker explains her experience on the deathbed when she died (Friedrich, 1955). The poem begins with the mentioning of the Fly, whose buzz is the only sound that can be heard in the still room. The Fly symbolizes the beginning of the decaying process of the body immediately when a person dies. The speaker also describes the stillness of the room where she dies, indicating dying as a weird experienced characterized by tension. When one dies, they are not alone as they are surrounded by mourners. In the second stanza, the speaker indicates that she could see other people by her side, probably the close relatives she had. She states that I willed my keepsakes-Signed awaydescribing her willingness to have her material possessions divided among her relatives and friends, but death strikes before she completes the task (Bachinger, 1985). The process of dying also involves the revelation of God as indicated by the speaker. In the second stanza, the speaker explains that the breaths gathered by the mourners await her last moment when the King would be present in her deathbed. The belief by the American Protestants at that time was that Jesus came to take one's soul upon their death, thus symbolizing the King as Jesus (Ickstadt, 2001). The mourners thus wait for a revelation from Jesus that the speaker has died. However, instead of a King, the living being witnessed in the room is the Fly, which symbolizes decay, probably indicating that the speaker's weak belief that life is divine.

The experience of death is also characterized by a lot of uncertainty. The speaker seems unable to comprehend some actions that take place during her death, probably because it is her first dying experience. In the third stanza, the speaker explains her confusion and uncertainty of the part of her possessions to give away -What portion of me be assignable- (Bachinger, 1985). There is no guideline or manual about the process of death that one can refer to when they die, thus it is likely that one might be uncertain about their responses in the process.

\subsection{Metaphor and Tone to Show the Process of Passing Away from the Standpoint of Eternity in the Poem "Because I could not stop for Death-"}

Eternity is the standpoint that life continues even after the physical death, because of the immortality of the soul. In the poem "Because I Could Not Stop for Death," the poet uses metaphor and a calm tone to describe the process of death and entry into new eternal life (Dickinson \& Howe, 2004). Metaphors are words that do not have a literal meaning in a text (Charteris-Black, 2016). Poets use tones effectively to describe their attitude towards the content of the poem. It is through the tone that the readers understand the exact meaning of the poem.

One of the tones used by the speaker is lightheartedness as indicated by the fact that she accepts death as it is. Although death is a sad event that causes emotional grief to the bereaved, Dickinson presents it as a normal and adventurous process. The speaker describes death as civil and patient, eliminating the negative aspects that it is associated with (Gerhardt, 2006). The other tone that describes death is solemn, as indicated by the seriousness of the subject of death. In the beginning, the speaker understands death as a simple and natural process and she does not give it the attention it deserves. In the first stanza, the speaker cites-Because I Could Not Stop for Death-, indicating that she is too busy with her daily activities to think about death (Dickinson \& Howe, 2004). However, she later realizes the seriousness of death and is even willing to give up her leisure and labor for death's sake. The poem also indicates shock in its tone, as indicated by the fact that it occurs when the speaker is unprepared (Hamid, 2007). Death finds the speaker busy with her life.

In literature, metaphors are used to compare different aspects that have similar features to bring out the intended meaning of the text. In the first stanza, Dickinson uses carriage as a metaphor where she indicates that it is driven by death, accompanied by immortality (Green, 2012). In the literal meaning, the carriage refers to a vehicle or any means used to transport goods from one place to the other. The meaning of carriage in the sentence presents death as a human being who makes an effort to woo a suitor. The true meaning of carriage as used by the speaker is the journey of life that people undergo. The carriage takes the speaker away from life, as she indicates that they pass she leaves life behind- We passed the school, where children strove-, an indication that she passed on from the living to another world (Gilpin, 2014). The speaker cites that- description of the 
carriage indicates that it is not average-The carriage held just but Ourselves and immortality-, indicating that it is an extraordinary carriage (Freeman, 2000). The nature of the carriage indicates that it represents a larger idea than just traveling. It presents the idea of death and the beginning of a new life since it is said to carry immortality with it.

The other metaphor used in the poem is the house, which indicates the grave. The speaker indicates that the carriage stops at a house that looked like a swelling on the ground (Hamid, 2007). The house is described as having a scarcely visible roof, indicating that the speaker could clearly see the house. In the literal meaning, a house is used as a resting place, which can be permanent or temporal. In the poem, the speaker occupies the house temporality as she awaits the next stage of life. The house or the grave is just a temporary place where the speaker rests before continuing with the journey to eternity. It symbolizes the change in the living form; from life to eternity.

The character of death is also used as an extended metaphor to present the journey towards eternity. Death is described as having human attributes such as the ability to drive and to show kindness. The speaker explains that death offers to give her a ride in the carriage, which indicates the transition from death to eternal life (Nasaru, Katili, \& Podungge, 2013). Together with death and immortality, the speaker passes school children which indicate her transition from life to death. The stop that the carriage occupants make at the grave indicates the beginning of a new life of eternity.

\section{Conclusion}

The rich language and symbolism used by Dickinson make both poems interesting and highly informative. This language also enhances the ability of the audience to understand her vision of death. In the poem, "Because I Could Not Stop for Death," Dickinson succeeds in transforming the negative image that presents death. The calm tone used in the poem makes the audience think about death as a normal and less horrifying experience as one would imagine. Additionally, the personification of death as a suitor eliminates the horror that it is associated with. The speaker even states that she gives in her leisure to enjoy the civility shown by death. Dickinson uses metaphors to illustrate death; making the audience change the perception they hold about it as strange, and view it as a normal occurrence.

In the poem, "I Heard a Fly Buzz-When I Died," Dickinson describes the process of dying and effectively shows her attitude towards death and immortality. The poem presents death as a painless but horrifying process where one's body starts to decompose. The poem also indicates her religious doubt and forces the audience to think critically about death and afterlife. The transcendentalist views used by the poet in presenting her vision about death challenge the audience to think deeply about life not just about death.

\section{References}

Ambarwati, T. W. (2006). The Influence of Emily Dickinson's Life Background on the Concept of Death Found in her Poem Entitled "Because I Could Not Stop for Death" (Doctoral dissertation, Universitas Negeri Semarang).

Bachinger, K. (1985). Dickinson's I Heard a Fly Buzz. The Explicator, 43(3), 12-15. https://doi.org/10.1080/00144940.1985.9938607

Charteris-Black, J. (2016). Politicians and Rhetoric: The Persuasive Power of Metaphor. Springer.

Dickinson, E. (1933). The Poems of Emily Dickinson. Hayes Barton Press.

Dickinson, E., \& Howe, S. (2004). Because I could not stop for Death. ProQuest LLC.

Doost, N. Z., \& Jamili, L. B. (2014). Actualizing Identity, Self-Actualization in Emily Dickinson's Poetry. A Paper.

Faur, E. (2012). The Metaphors for Death and the Death of Conceptual Metaphors in Poetry. An Analysis Based on Emily Dickinson's Poem "Because I Could Not Stop For Death". In International Conference on Languages, E-Learning and Romanian Studies.

Freeman, M. H. (2000). Poetry and the scope of metaphor: Toward a cognitive theory of literature. Metaphor and metonymy at the crossroads: a cognitive perspective, Antonia Barcelona, ed, 253-281.

Friedrich, G. (1955). 35. Dickinson's I Heard a Fly Buzz When I Died. The Explicator, 13(6), 84-87. https://doi.org/10.1080/00144940.1955.11481800

Gallagher, L. P. (2007). Emily Dickinson: The Language of a Spiritually Peripheral Perspective (Doctoral dissertation, Florida Atlantic University Boca Raton, Florida). 
Gerhardt, C. (2006). "Often seen-but seldom felt": Emily Dickinson's Reluctant Ecology of Place. The Emily Dickinson Journal, 15(1), 56-78. https://doi.org/10.1353/edj.2006.0020

Gilpin, W. C. (2014). Religion Around Emily Dickinson (Vol. 2). Penn State Press.

Green, J. W. (2012). Beyond the Good Death: The anthropology of modern dying. University of Pennsylvania Press.

Hamid, A. (2007). Figures of Speech Analysis on Emily Dickinson's Poems a paper.

Hughes, G. (2014). Love, Terror, and Transcendence in Emily Dickenson's Poetry. Renascence, 66(4), 283. https://doi.org/10.5840/renascence201466421

Ickstadt, H. (2001). Emily Dickinson's Place in Literary History; or, the Public Function of a Private Poet. The Emily Dickinson Journal, 10(1), 55-69. https://doi.org/10.1353/edj.2001.0005

Leiter, S. (2007). Critical Companion to Emily Dickinson: A Literary Reference to her Life and Work. Infobase Publishing.

Morgan, V. N. (2010). Emily Dickinson and Hymn Culture: Tradition and Experience. Ashgate Publishing, Ltd.

Nasaru, M., Katili, A. A., \& Podungge, R. (2013). Personification in Emily Dickinson's Poems. KIM Fakultas Sastra dan Budaya, 1(1).

Yan, Z. (2010). Passion in Emily Dickinson's poems-on the motives of nature, love and death. Journal of Henan Institute of Science and Technology, 11, 16.

\section{Copyrights}

Copyright for this article is retained by the author(s), with first publication rights granted to the journal.

This is an open-access article distributed under the terms and conditions of the Creative Commons Attribution license (http://creativecommons.org/licenses/by/4.0/). 